度最適量儿相虽するとる考学られるが，同持に吒解後 適度にフィプッル化された繶維の形態か强勒な紙葉の

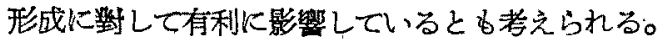

以上の結果から判るように，互硫酸法或は硫酸愠法 による輕度の前處理と組合わせた木ロセルローズ法は， 特に强力な漂白紙の盤造に對して極めて有用な一方法 として，工業的にる興味ある問題でるるら。

$$
\text { 第 } 4 \text { 表 }
$$

\begin{tabular}{|c|c|c|c|c|c|c|}
\hline \multirow{2}{*}{ “試驗項目 } & \multicolumn{3}{|c|}{ 亞硫酸法 } & \multicolumn{3}{|c|}{ 硫酸監法 } \\
\hline & $\begin{array}{c}\text { 試料 } \\
\text { A }\end{array}$ & $\begin{array}{c}\text { 試料 } \\
\text { I }\end{array}$ & $\begin{array}{c}\text { 試料 } \\
\text { II }\end{array}$ & $\begin{array}{c}\text { 試料 } \\
\text { B }\end{array}$ & $\begin{array}{c}\text { 試料 } \\
\text { III }\end{array}$ & $\begin{array}{c}\text { 試料 } \\
\mathbb{I N}\end{array}$ \\
\hline 吒解度 ( ${ }^{\circ}$ S.R.) & 40 & 40 & 39 & 41 & 40 & 38 \\
\hline 裂斷 長 $(\mathrm{km})$ & 5.3 & 8.1 & 6.4 & 5.8 & 7.9 & 6.6 \\
\hline 比破 裂 度 & 3.6 & 5.3 & 4.1 & 4.0 & 4.8 & 4.1 \\
\hline 可 裂 & 95 & 95 & 107 & 124 & 168 & 140 \\
\hline 犐揉 回 数 & 1250 & 1950 & 1550 & 1700 & 2580 & 1620 \\
\hline
\end{tabular}

\section{4 碎木パルプの亞監素酸監虑理}

碎ホバルブを通常の互硫酸法或は硫醉監法で蒸解す ると泥狀物となり使用に堪えない。併し亚盖素酸ソー ダの酸性水溶液で庭理し脫リグニンすると，叮解庭は 高いが充分抄紙し得る紙料が得られる。而して前報に 迅一檍儿，かかる紙料から造られる紙はグラシン紙

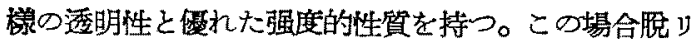
グニンと同特に，一舉に吅解度 $90 \sim 92^{\circ}$ S.R. の紙料 が得られることは特に興味岕る開題である。

普通の木材バルブを叮解したものと異つて，頑りグ ニン碎木紙料の叮解狀態は, 瀻維片が縱裂され又緎維 表面が著しく剝離されていると言う特徽を持つことが 顯微鏡的に認められる。かかる叨解形態と一ミセル口 ーズ含有量の多いことが，これから造つた紙に上述の

\section{ような特性を與えるもので㐫ろう。}

脫りグニン碎木パルブより抄造した紙の性質に閔し ては前報で詳迅した。本報には人緎用バルブにかかる 紙料を睢々の割合に湿合抄造した紙の强度的性質を第 5表として示した。脫りグニンした碎木バルブはこの 樣に充填紙料としてす大きい價值を有ることが制る。 第 5 表

\begin{tabular}{|c|c|c|c|c|c|c|c|}
\hline \multirow{2}{*}{\multicolumn{3}{|c|}{ 試 驗 項 目 }} & \multicolumn{5}{|c|}{ 碎木ホロセルローズ湦合來 $(\%)$} \\
\hline & & & 0 & 25 & 50 & 90 & 100 \\
\hline & 水 度 & cc) & 700 & 550 & 460 & 220 & 90 \\
\hline 裂 & 断 & $\mathrm{cm})$ & 2.4 & 3.1 & 4.1 & 7.0 & 6.9 \\
\hline 比 & 破 裂 & 度 & 1.7 & 2.1 & 2.7 & 4.8 & 4.8 \\
\hline 引 & 裂 & 度 & 62.3 & 67.6 & 72.0 & 84.1 & 84.0 \\
\hline 而 & 揉 回 & 数 & 65 & 175 & 490 & 1553 & 1110 \\
\hline 白 & 色 & 度 & 85 & 82.5 & 77 & - & - \\
\hline 不 & 揫 明 & 度 & 79.0 & 75.4 & 73.0 & 65.4 & 64.5 \\
\hline
\end{tabular}

\section{5 總 括}

ホロ七ルローズ含有量の多い紙として，纎䊒狀ホロ せルローズ，牛蒸解バルプ皮び碎木バルプの木ロれル ローズから調製した紙を葓び，その性質に检討を加え た。之等の紙は紙質が透明で裂断，破裂及び耐探等の 强度的性質は傮れ，引裂度が劣ると言う共通した性質

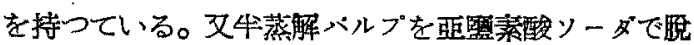
リダニンしたバルプが特に强力な紙を與えること，及 び碎木バルブが單に眖りグニンするだけで一擧に吅解

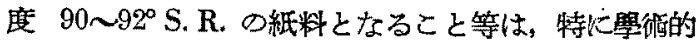
Kる又工學的應用上にも興味深い。

向本矿究の大要は炤和 25 年 10 月较維學會關西支部

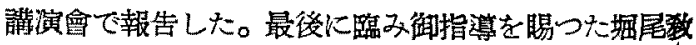
授並に御援助下さつた雷田时教授に梁謝する。

（昭和 27 年 6 月. 20 日受理） 677.021 .7

\title{
蔡切機構に關する研，究
}

\section{第 1 報 率切機構の定常狀態について}

\section{東京工業大學石川章一自畑昌顯}

\section{1 緒 譶}

直紡機するいはぞの他の率切蟣の率切野における瀻
維群の學動，その分布狀態を明らかにすることは製品

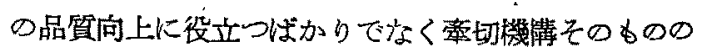
設計に對しても甚だ有用でする。本研究は2 組のロー 
ラからなる最る基本的な率切機筹について基磉的な研 究を行い，その性質を明らかにしようとするるのです つてもつて率切機愫研究の一助にしたいと思ら。

本報は牽切機溝の解析方浩を研究し，その定常狀態 における瀻維群の狀態を明らかにするすのでする。

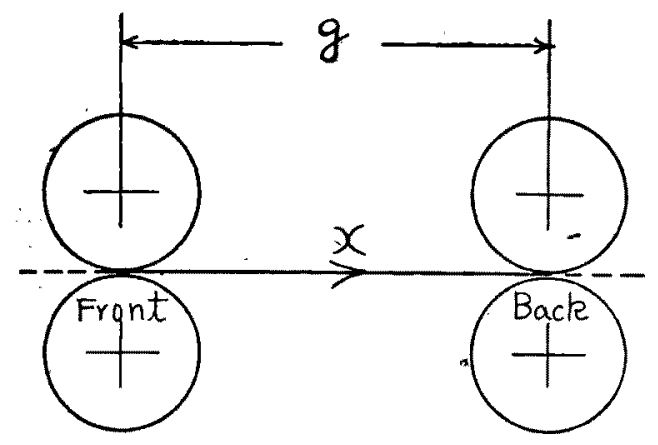

Fig | Draft-Cutting Mechanism

\section{2 解析の方法}

第 1 圖は該機龇を示す。記號は次のよろに定める。

$g: \quad$ ゲージ長

V1. フロントローラの表面速度

$V_{2} ： \quad$ バッタローラの表面速度

$D=V_{1} / V_{2}$ ドラフト比

$M: \quad$ 原料ドゥの構成瀻維數

$l$ ：切斷するまでに食い出される纎維の長さ （以後單に切歁食い出し長と呼ぶ）の本 均值

$L, L^{\prime}$ ： 㽖斷食い,出し長の最大値と最小值

坐槽軸は圖に示すよ5に定め,フロントローラを原 點 $x=0$, バッククシダを $x=g$ とする。

(1) 礁立曲線 $p(x, t)$ 。

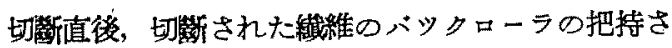
れた部分の先端が位置 $x$ ，支び時間 $t$ の函數 $p(x, t)$ に從つて分布する㭙，この $p(x, t)$ を確率曲線を䊩す る。切得後瀻維は收縮する放, $p(x, t)$ は切断點の分布

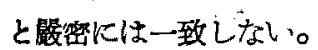

明らかに $x<0$ て

$$
\int_{x}^{a} p(x) d x=\int_{0}^{a} p(x) d x=1
$$

(2) 慗切曲線 $D(x, t)$

切曲線はすでに早川稫雄氏が本誌上で1) 定義され

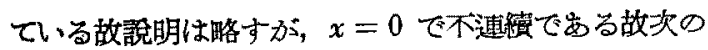
よろな考慮をして連緼にする必要がある。すなわちこ

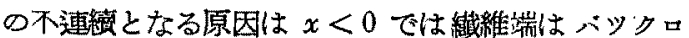
一ラの逨度で移動するが，x<0ではフロントローラ の速度で移動することによる故に $x<0$ に怙いては長 さを $1 / D$ 倍にとることにすれば連續となる。以後坐 標はすべてこのようにとる。

第 2 圖は率切曲線 $D(x, t)$ を示し次の性質を有す る。

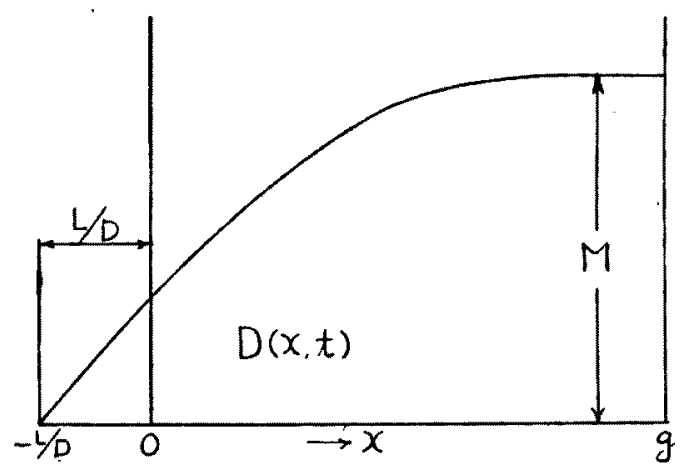

Fig 2 Draft-cutting curve

(I) $D(-L / D, t)=0$

(II) $D(0, t)=N$ 率伸されつつ方る纎維数

( III) $D(g, t)=M$ 原料卜市の構成瀻維數

(3) 分布曲線 $F(x, t)$

慗切曲線 $D(x, t)$ を $x$ につき微分するとゲージ

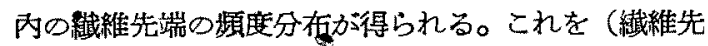
端の）分布曲線と呼び, $F(x, t)$ で表わす。またフ ロントローラK把持された䜟維は甽斷食い开し長に等 しい長さだけ食いこまれると切斷される。この切斷食 い出し長は勿論一定でなく，原料瀻維の性質，紡續條 件等により決定されるる分布をするが，原料繊維と同傢

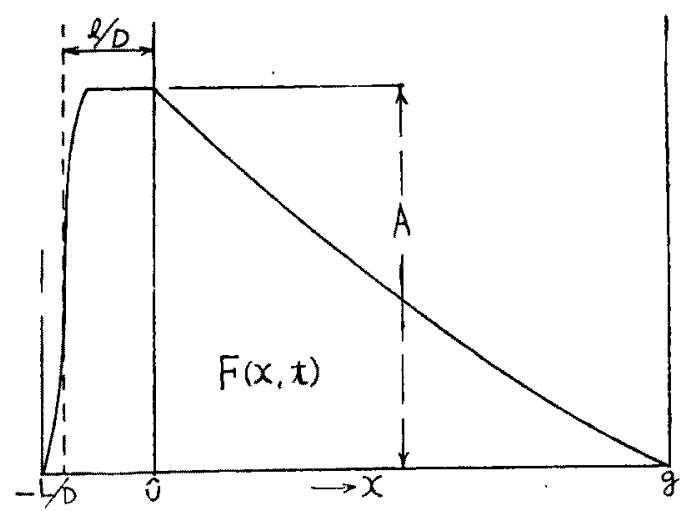

Fig.3 Distribution curve for the" front ends of filaments 


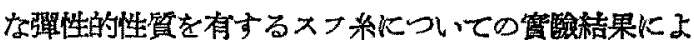
ると略々正規分布に近い分布をすることが示された。

從つて分布曲線 $F(x, t)$ は第 3 圆㨬示すよらなる のとなり，次の性筫を有する。

$$
\begin{gathered}
\text { (I) } D(x, t)=\int_{-L \mid D}^{x} F(x, t) d x \\
\text { (II) } M=\int_{-L / D}^{o} F(x, t) d x \\
\text { (II) } L^{\prime} \leqq x \leqq 0 \text { て } F(x, t)=F(0, t) \\
\text { (IV) } \int_{-L / D}^{o} F(x, t) d x=\int_{-l / D}^{0} F(0, t) d x \\
=F(0, t) l / D
\end{gathered}
$$

(4) 切㪚曲線 $H(t)$

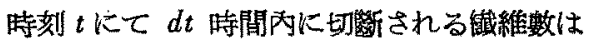
$V_{2} F\left(0, t-l_{1} V_{1}\right) d t$ であ。あらためて $V_{2} F\left(0, t-l / V_{1}\right) d t=H(t) d t$ と扣き，この画数 $H(t)$ を切断曲線と定義する。

\section{3 米, あるいはスライバの斷面 構成㵶維數}

时刻 $t$ Kてフロントンローラから紡出されだ部分の 米またはスライバ(以後單に系とする) ゆ單位長さに

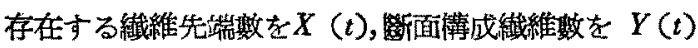
とすると，以上の定義から切斷後のフロУトローラに 把持された繊維の後端の分布が $p(x)$ K一效すると 假定して次式が誘導される。

$$
\begin{aligned}
& X(t)=H(t) / D \\
& Y(t)=\int_{\ell}^{\alpha} H(v) d v+\int_{\beta}^{t} H(v) d v \int_{\gamma}^{a} p(x) d x(6) \\
& \text { ここて } \alpha=t+l / V_{1} \\
& \beta=t-g / V_{1} \quad \gamma=V_{1}(t-v)
\end{aligned}
$$

まだはは記述の都合上， $t$ の代りに用いたるのである。

(5)式は約の聯面瀻維数を表わし，系の太さるるは 系の重量を表わするのではない。重量を求めるには睝

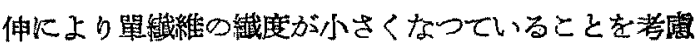
する必要が要る。

\section{4 定常狀態について}

確率曲線 $p(x, t)$ 及び分布曲線 $F(x, t)$ 方時間に 無關係で $x$ わの画数である場合炕は，明らかに

$$
F(0, t)=H(t) / V_{2}=\text { const }
$$

この常数を $A$ と括く之次の方程式が成立する。

$$
d F / d x+A p(x)=0
$$

これをといで,

$$
F \infty(x)=A \int_{x}^{0} p(u) d u
$$

suffix $\infty$ の意味につ、ては後に述げる。

(8)式の兩䢬をさらに $x$ Kつを $-L / D$ より $g$ まで䅡 分すると，左傻は(2)式によつてトウの轱䧴数 $M$ K等 しくなりこれと(4)式から

$$
\begin{aligned}
& M=\int_{-L \mid D}^{g} F \infty(x) d x=A \int_{-\imath \mid D}^{0} d x \int_{x}^{y} p(u) d u \\
& \therefore A=M / \int_{-u \mid D}^{g} d x \int_{x}^{g} p(u) d u
\end{aligned}
$$

また $H(t)=V_{2} A$

故に糸の斷面瀻維數はこれを(6)式に代入し

$V_{1}(t-v)=z$ と颃いて

$$
Y(t)=A l / D+\int_{0}^{g} \frac{\mathrm{A}}{\mathrm{D}} d z \int_{z}^{g} p(u) d u
$$

(4)式原よれば $A l / D=\int_{-L / D}^{0} F \infty(x) d x$

これと(8)式とにより(10)式は

$$
\begin{aligned}
& Y(t)=\frac{1}{D} \int_{-L / D}^{g} F \infty(x) d x+(1-1 / D) \frac{A l}{D} \\
& \quad=M / D+(1-1 / D) A l / D
\end{aligned}
$$

(11)式によれば定常狀態にるる兼の糍面瀻維數は原物 トウの構成瀻緶の $1 / D$ 倍より $(1-1 / D) A l / D$ だけ多 い。これは一見奇異に思えるが，すで第 3 章で說明 したように等伸によつて織維が細くなつていることに 原因する。すなわら切斷食い出し長 $l の 一$ 部 $V_{2} \times l / V_{1}$ $=l / D$ は伸びた部分であるのでこれを(10)式の第 1 項に 考慮すると第 1 項の筫の重量は

$$
A l / D-(1-1 / D) A l / D=A l / D^{2}
$$

となり系の重量を表わす式を $y(t)$ とすれば次のよう になる。

$$
\begin{aligned}
y(t) & =A l / D^{2}+\frac{1}{D} \int_{x}^{g} F \infty(x) d x \\
& =\frac{1}{D}-\int_{-L / D}^{g} F_{\infty}(x) d x \\
& =M / D
\end{aligned}
$$

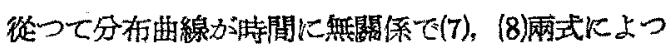
て决定される犆をとるならは旁切機棈は定常狀態を保 つ。この(7)，(8)兩式の示す分存曲線を特化定常分布曲 線と稱し， $F \infty(x)$ と㫪くことにする。

第 4 ，第 5 圆はドラフト比 2.0 K括ける代表的な $p(x) \oplus 3$ 例と，それに徨する $F \infty(x)$ とを示す。

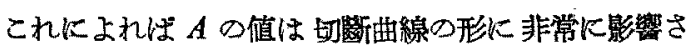
れることがわが。このAの大小は等切比要する仕事 量などと密接な閵保がする。

\section{5 定常狀態を保つ保件}




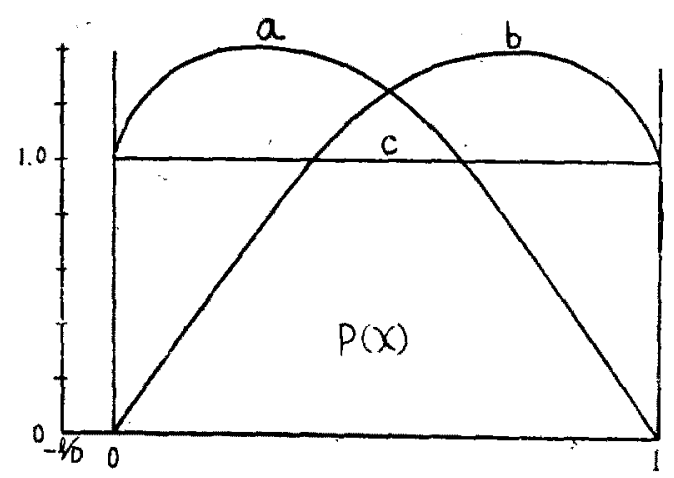

Fig 4. Protability curve

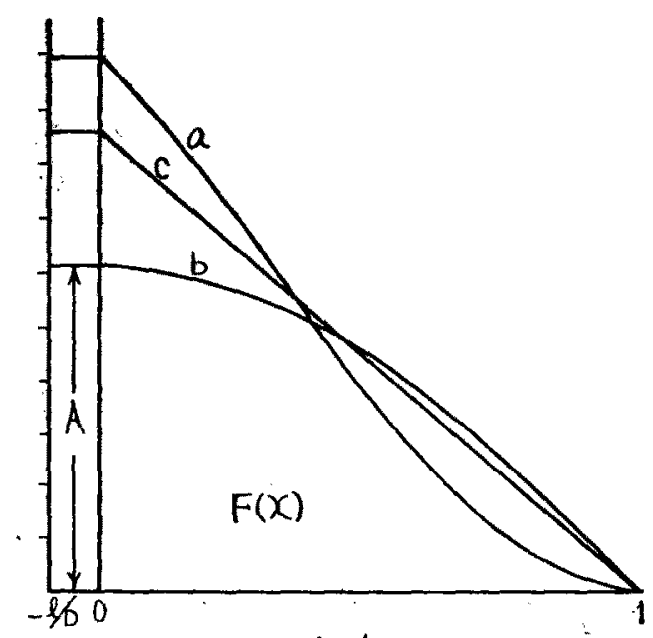

Fig 5. Distrifition curve

系に生じないためには浑切機棈が定常狀態を保 つことが必要でする。第2 報で報告する踭定の單位斑 の理論によ机ば，確率曲線 $p(x, t)$ 加時闑によつて

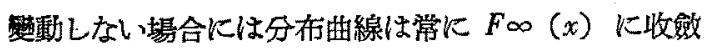
する性筫がある。しかるに分布曲線が $F_{\infty}(x)$ を保て ば箽切譏構は定常狀態を保つことがすでに證明された。 從つて確慗曲線 $\mathrm{p}(x, t)$ が位置 $x$ の小函数で交り 時留によつて弶動しないことが定常でるるための必姴 惵件である。（充分ではない）

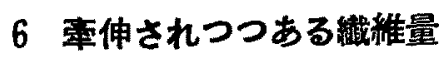

率伸されつつます織維量を $N$ とすれば， $N$ は明ら 加䋘維先端が $x<0$ に存在する䋐維の總和以等し

く、また $D(0, t)$ K等しい。すなわ占

$$
N=\int_{-L / D}^{o} F \infty(x) d x=D(0, t)
$$

さらに(4)式及び第 4章で說明したところにより

$$
N=F(0, t) l / D=A l / D
$$

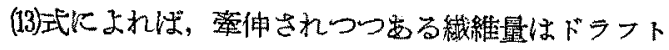

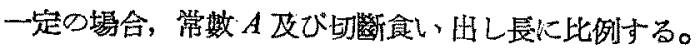
$A$ 及び $l$ 具體的數值については第 3 報で研究する予象 定でをる。

\section{7 フロントローラの把持曲線と分布曲線}

定常狀態でフロントローラに把持されている高速繳 維群の量が，位置 $x$ の函數 $G(x)$ で麦わされたとす ると $G(x)$ は次の上万になる。

$$
G(x)=A l / D+\frac{1}{D} \int_{x}^{a} F \infty(z) d z
$$

ここで第】項は同時にバッククローラに把持されて等 伸されつつ出る瀻維量を示す。またフロントローラに 把持された維維の啳端の分有を示す分有曲線を $G^{\prime}(x)$ とすると

$$
G^{\prime}(x)= \pm F \infty(x) / D
$$

負號は把持曲線 $G(x)$ が單調減少函數ですることに よる。ここでは綗維後端の数を間題にする故，常に正 と洘えて差支光い。

\section{8 結 語}

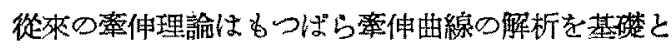
して考察されていいが，筆者等は新たに分布㑋線なる 概念を設け，それによる解析方滛を用いて2 組のロー ラからなる䇣切機對の定常狀態を明らかにした。その 結果

(1) 率切機擈が定常であるためには磪率曲線 $p(x, t)$ が定常でなければならぬ。

（2）低速䋐維の分布曲線 $F \infty(x)$ は(8)，(9)网式より

$$
F \infty(x)=M \int_{x}^{q} p(u) d u / \int_{x>0}^{g} d x \int_{x}^{g} p(u) d u
$$

(3) 高速繊維群の分布曲線は (15)式より

$$
G^{\prime}(x)=F \infty(x) / D
$$

(4) 慗伸されののるる䋘維の量は (13)式より

$$
N=F(0, t) l / D=A l / D
$$

（5）紡績された糸むるいはスライバの知面緎維數は (11)式正 b

$$
Y(t)=M / D+(1-1 / D) A l / D
$$

以上の理諭は簤驗により確めることができたが，こ

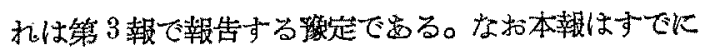
昭和 25 年故維學會春期登表會で登表した。

\section{交献}

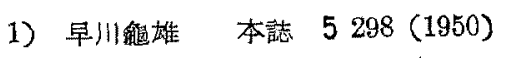

